\title{
PENGARUH MOTIVASI BELAJAR DITINJAU DARI JENIS KELAMIN TERHADAP KEMAMPUAN BERPIKIR KRITIS MATEMATIS MAHASISWA
}

\author{
Ika Wahyu Anita \\ anita.iw2013@yahoo.com \\ Program Studi Pendidikan Matematika, STKIP Siliwangi
}

\begin{abstract}
ABSTRAK
Penelitian ini dilatar belakangi oleh rendahnya kemampuan berpikir kritis mahasiswa pendidikan matematika. Akan dicari faktor yang mempengaruhi tinggi rendahnya kemampuan tersebut. Tujuan dari penelitian ini adalah untuk mengetahui apakah terdapat pengaruh motivasi belajar mahasiswa ditinjau dari perbedaan jenis kelamin terhadap kemampuan berpikir kritis matematis, kemudian untuk mengetahui faktor-faktor apa saja yang mendukung serta menghambat motivasi belajar mahasiswa. Sampel penelitian yang diambil adalah mahasiswa yang menempuh mata kuliah Struktur Aljabar II di STKIP Siliwangi Bandung berjumlah 84 orang. Penelitian ini merupakan penelitian expost-facto. Data-data penelitian diambil dari angket mahasiswa, wawancara dan tes tertulis untuk mengukur kemampuan berpikir kritis matematis mahasiswa pada mata kuliah Struktur Aljabar II. Hasil penelitian menunjukkan adanya perbedaan motivasi belajar ditinjau dari jenis kelamin, namun tidak terdapat perbedaan yang signifikan dalam kemampuan berpikir kritis matematis ditinjau dari perbedaan jenis kelamin.
\end{abstract}

Kata kunci: motivasi belajar, jenis kelamin, kemampuan berpikir kritis matematis

\begin{abstract}
This study was motivated by the low of critical thinking skills of the mathematics education students. Will be searched the factors that affecting the capabilities. The purpose of this study to determine the influence of learning motivation (in terms of the gender differences) to the ability of mathematics critical thinking, then to determine what factors that support and hinder the learning motivation. The research sample is 84 students who take Structure of Algebra II in STKIP Siliwangi Bandung. This study used expost-facto research. The data taken from the students questionnaires, interviews and the mathematics critical thinking test. The results showed the differences learning motivation in terms of the gender differences, but not significant for the mathematics critical thinking.
\end{abstract}

Keywords: learning motivation, gender, math critical thinking

\section{A. PENDAhuluan}

Menghadapi diberlakukannya Asean Economic Community (AEC) pada tahun 2015 ini, sangat dibutuhkan sumber daya manusia (SDM) yang handal, berdaya cipta dan mampu berinovasi. Masih menjadi andalan bahwa pendidikan dijadikan sebagai sarana untuk menghasilkan SDM seperti yang dibutuhkan. Bukan hanya SDM seperti diatas yang akan dapat bertahan menghadapi persaingan yang makin ketat, namun juga dibutuhkan pribadi-pribadi yang arif, bijaksana, tangguh dan mandiri. Sehingga penanaman karakter juga menjadi titik penting dalam pelaksanaan pendidikan di sekolah. Pendidikan yang terurai dalam satuan-satuan pembelajaran di kelas harus di-setting sedemikian rupa sehingga bukan hanya menitikberatkan pada penanaman nilai-nilai kognitif namun juga dapat menjadi sarana penanaman karakter.

Menjawab tantangan dan tuntutan tersebut, pemerintah memiliki tugas untuk dapat menyusun suatu pembelajaran yang tepat dan terpadu sehingga seluruh aspek yang dibutuhkan dapat terpenuhi dalam pembelajaran. Keterpaduan ini bukan hanya diberlakukan di satu jenjang pendidikan saja, namun harus menjadi alur berlanjut sejak pendidikan dasar hingga pendidikan tinggi. Hal ini diharapkan penanaman kognitif, afektif, psikomotor dan nilai-nilai karakter dapat 
menjadi ilmu dan tabiat yang melekat dalam peserta didik.

Peran pendidik masih sangat dominan dalam tujuan besar tersebut. Dominan yang dimaksud dalam hal ini bukan sebagai penguasa kelas dimana seluruh pembelajaran terpusat kepadanya. Pendidik dituntut untuk multi-tasking, mengajarkan ilmu, melatih, mendorong, menstimulus sekaligus menjadi teladan. Peran pendidik bukan hanya fasilitator pembelajaran, tapi juga harus mampu memasukkan nilai-nilai karakter dalam pembelajarannya.

\section{B. KAJIAN TEORI DAN METODE}

\section{Kajian Teori}

Seperti pendapat Agustian (2007) dalam bukunya yang mengatakan bahwa pendidik perlu melatih dan membentuk karakter anak. Salah satu kecakapan hidup (life skill) yang perlu dikembangkan melalui proses pendidikan adalah keterampilan berpikir (Depdiknas, 2002). Hal ini merupakan salah satu ukuran keberhasilan dan ketercapaian tujuan pendidikan. Kemampuan dan ketrampilan berpikir adalah syarat seseorang untuk dapat berhasil dalam kehidupannya antara lain dalam upaya memecahkan masalah-masalah dalam kehidupan yang dihadapi.

Proses memecahkan masalah tersebut bukan hal yang mudah, namun harus melalui serangkaian proses. Fase berpikir yang paling awal adalah adanya kepekaan seseorang terhadap masalah yang dihadapi, kemudian melakukan analisa untuk dapat menentukan langkah-langkah alternatif yang dimungkinkan dapat menyelesaikan permasalahan tersebut. Keberanian seseorang untuk trial and error dalam mencari solusi merupakan faktor yang berpengaruh terhadap kemampuan seseorang mengembangkan proses berpikirnya.

Salah satu kemampuan yang harus dikembangkan yaitu kemampuan berpikir kritis dan kreatif. Kecakapan mahasiswa dalam mengembangkan proses berpikirnya dapat menjadi salah satu indikasi berkembangnya ketrampilan berpikir. Hal ini diharapkan dapat menjadi bekal saat mereka harus bersaing dalam tuntutan globalisasi.

Selanjutnya Ruggiero (Johnson, 2007) menyatakan berpikir kritis merupakan sebuah keterampilan hidup, bukan hobi di bidang akademik, sehingga mahasiswa perlu dilatih untuk mengembangkan kemampuan ini. Sedangkan Ennis (1996) mendefinisikan berpikir kritis sebagai sebuah proses berpikir yang bertujuan untuk menghasilkan keputusan yang rasional untuk memutuskan untuk meyakini atau melakukan sesuatu. Kemampuan berpikir kritis merupakan kemampuan yang didalamnya juga dikembangkan kemampuan untuk berpikir kreatif. Sedangkan mata kuliah Struktur Aljabar II dipilih karena karakteristik mata kuliah tersebut menuntut mahasiswa untuk bernalar dan kritis dalam menjelaskan dan membuktian suatu definisi, aksioma, teorema dan aplikasinya.

Dalam proses pengembangan kemampuan kritis sangat dipengaruhi oleh motivasi belajar. Motivasi dikutip dari Nasution (1986) yaitu adanya usaha untuk menyediakan kondisi-kondisi tertentu sehingga seseorang mampu dan ingin melakukan sesuatu. Sedangkan belajar menurut Sardiman (2005) adalah usaha penguasaan materi ilmu pengetahuan yang merupakan sebagian dari kegiatan membentuk kepribadian seutuhnya.

Pendapat tersebut menunjukkan definisi belajar dalam arti sempit yaitu dalam ruang lingkup pembelelajaran di ruang-ruang kelas. Sehingga disimpulkan bahwa motivasi belajar yang dimaksud dalam penelitian ini adalah usaha yang tumbuh dalam diri mahasiswa yang mendorongnya untuk menguasai materi-materi perkuliahan.

Diduga bahwa motivasi yang muncul dari dalam diri mahasiswa berpengaruh terhadap pencapaian kemampuan yang diharapkan. Sedangkan diduga pula bahwa muncul atau tidaknya motivasi belajar mahasiswa yang mempengaruhi proses berpikir kritis matematisnya dipengaruhi oleh perbedaan jenis kelamin. Seperti yang dikemukakan oleh Makmun (2004) yang menyatakan bahwa faktorfaktor yang mempengaruhi motivasi antara lain adalah usia, jenis kelamin, kondisi fisik, kemampuan dan suasana lingkungan.

Faktor gender atau jenis kelamin diambil karena diduga adanya perbedaan prestasi antara mahasiswa laki-laki dan perempuan. Seperti pendapat Baron \& Byrne yang mengatakan bahwa gender secara tidak langsung berpengaruh terhadap pembentukan sikap dan motivasi belajar (Hoang, 2008). Dalam jurnalnya Hoang (2008) mengungkapkan bahwa laki-laki dengan semua karakteristik bawaannya berbeda dengan perempuan. Perbedaan-perbedaan tersebut diduga berpengaruh dalam setiap aspek kehidupan yang dialami. Hal inilah yang mendorong penulis untuk 
melakukan penelitian dengan judul "Pengaruh Motivasi Belajar Ditinjau dari Jenis kelamin Terhadap Kemampuan Berpikir Kritis Matematis Mahasiswa".

\section{Metode}

Metode dalam penelitian menggunakan pendekatan expost-facto dimana penelitian yang dilakukan dengan pengkajian mengenai pengaruh motivasi belajar terhadap kemampuan berpikir kritis matematis ditinjau dari pengaruh jenis kelamin.

Penelitian ini dilaksanakan di lingkungan STKIP Siliwangi dengan sampel yang dipilih adalah mahasiswa program studi pendidikan matematika yang menempuh mata kuliah Struktur Aljabar II sebanyak 84 orang.

Data diperoleh dari hasil pengisian angket tertutup yang berisi data isian tentang jenis kelamin, usia dan pernyataan-pernyataan berkaitan dengan motivasi belajar. Angket tersebut diisi dengan lima opsi pilihan jawaban yaitu "sangat setuju", "setuju", "netral", "tidak setuju", dan "sangat tidak setuju" dengan penskoran sesuai skala Likert. Sedangkan kemampuan kritis matematis diukur dengan menggunakan tes soal uraian sebanyak 4 soal pada mata kuliah Struktur Aljabar II. Data kualitatif ditambahkan berupa wawancara dengan dosen pengajar mata kuliah tersebut.

\section{HASIL DAN PEMBAHASAN}

Data yang diperoleh dari hasil ujicoba instrumen telah diuji pendahuluan yaitu uji normalitas dan homogenitas data. Analisis data dilakukan dengan bantuan Microsoft Excel 2007 dan SPSS 22.0. tabel berikut merupakan gambaran umum dari data keseluruhan.

Tabel 1. Rekapitulasi Data hasil Penelitian Ditinjau dari Perbedaan Jenis Kelamin

\begin{tabular}{ccccc}
\hline & JK & n & $\begin{array}{c}\text { Rata- } \\
\text { rata }\end{array}$ & St. Dev \\
\hline \multirow{3}{*}{ Motivasi } & L & 26 & 43,73 & 6,74 \\
& P & 58 & 42,71 & 7,00 \\
Skor tes & L & 26 & 10,88 & 1,20 \\
& P & 58 & 10,06 & 1,05 \\
\hline
\end{tabular}

Berdasarkan pada tabel di atas dapat diidentifikasi bahwa mahasiswa yang berjenis kelamin laki-laki sebanyak 26 orang rata-rata skor motivasinya sebesar 43,73 dan rata-rata skor berpikir kritisnya
10,88 dan mahasiswa yang berjenis kelamin perempuan sebanyak 58 orang dengan rata-rata skor motivasi 42,71 dan rata-rata skor berpikir kritisnya 10,06.

Analisis korelasi dilakukan untuk melihat ada atau tidaknya hubungan antara motivasi belajar dengan kemampuan berpikir kritis matematis mahasiswa. Selanjutnya analisis ini dapat digunakan untuk mengetahui bagaimana pola hubungan dan seberapa signifikan hubungan tersebut. Analisis dilakukan menggunakan rumus korelasi Pearson. Hipotesis penelitian dirumuskan sebagai berikut:

$H_{0}$ : ada hubungan yang signifikan antara motivasi belajar dengan kemampuan berpikir kritis matematis mahasiswa

$H_{1}$ : tidak ada hubungan yang signifikan antara motivasi belajar dengan kemampuan berpikir kritis matematis mahasiswa

Dengan taraf signifikansi $\alpha=0,05$ diperoleh data sebagai berikut:

Tabel 2. Hasil Uji Korelasi Movivasi Belajar dengan Kemampuan Kritis Matematis

\begin{tabular}{clrr}
\hline & & TOTAL & TOTAL \\
& MOTIVASI & KRITIS \\
\hline \multirow{2}{*}{ TOTAL } & Pearson Correlation & 1 & $0,218^{*}$ \\
MOTIVASI & Sig. (2-tailed) & & 0,047 \\
& $N$ & 84 & 84 \\
\multirow{2}{*}{ TOTAL } & Pearson Correlation & $0,218^{*}$ & 1 \\
KRITIS & Sig. (2-tailed) & 0,047 & \\
& $N$ & 84 & 84 \\
\hline
\end{tabular}

Dari Tabel 2 menunjukkan bahwa nilai signifikansi 0,047 yang berarti $\mathrm{H}_{0}$ diterima, sehingga diperoleh interpretasi bahwa ada hubungan antara motivasi belajar dengan kemampuan berpikir kritis matematis mahasiswa. Tinggi rendahnya kemampuan berpikir kritis matematis mahasiswa erat hubungannya dengan motivasi belajar mahasiswa tersebut.

Sedangkan, koefisien korelasi sebesar 0,218 menunjukkan bahwa pola hubungan yang terbentuk adalah hubungan searah. Hal ini menunjukkan bahwa jika motivasi belajar yang dimiliki mahasiswa tinggi maka kemampuan berpikir kritis matematisnya juga tinggi. Namun apabila motivasi belajar mahasiswa rendah maka akan diikuti dengan rendahnya nilai kemampuan berpikir kritis matematis mahasiswa. 
Data statistik diolah dengan uji-T dengan hipotesis sebagai berikut:

$\mathrm{H}_{0}=$ tidak terdapat perbedaan yang signifikan antara tingkat motivasi belajar mahasiswa laki-laki dan perempuan

$\mathrm{H}_{1}=$ terdapat perbedaan yang signifikan antara tingkat motivasi belajar mahasiswa laki-laki dan perempuan
Pada Tabel 4 diperoleh bahwa kemampuan berpikir kritis matematis mahasiswa menunjukkan nilai sig $0,533>\alpha=0,05$. Hal ini berarti $\mathrm{H}_{0}$ diterima, sehingga dapat disimpulkan bahwa “ Tidak terdapat perbedaan yang signifikan antara kemampuan berpikir kritis mahasiswa yang berjenis kelamin laki-laki dengan kemampuan berpikir kritis mahasiswa yang berjenis kelamin perempuan.

Tabel 3. Hasil Analisis Motivasi Belajar Ditinjau dari Jenis Kelamin

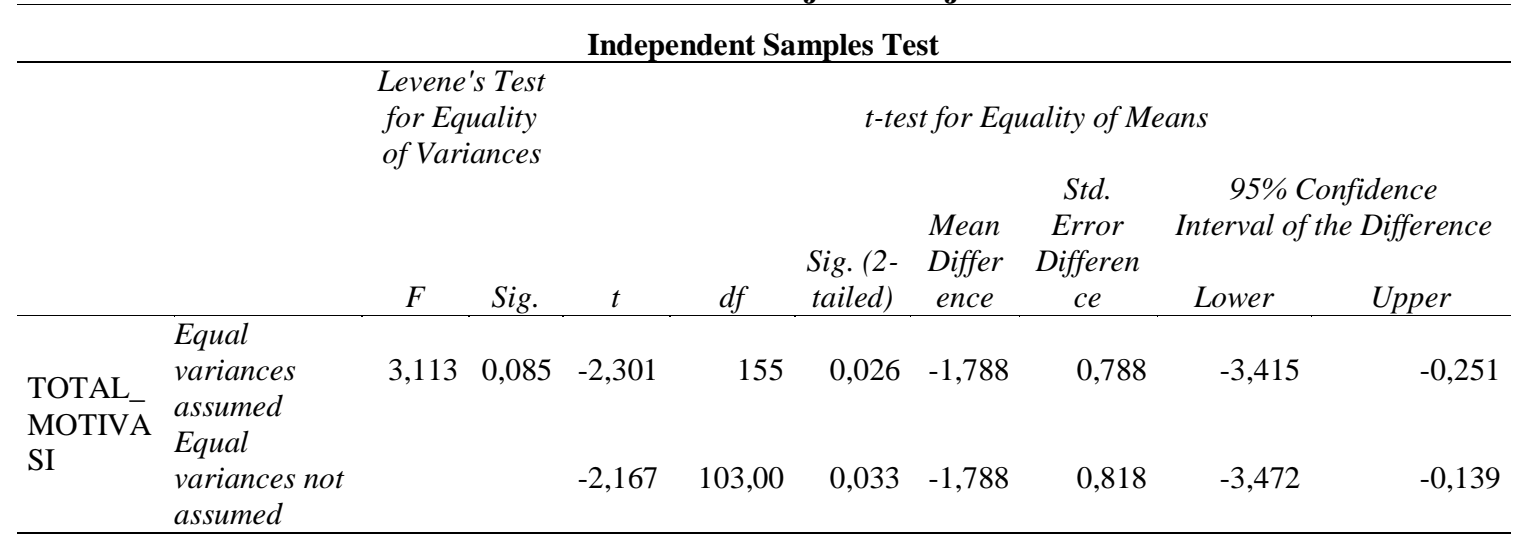

Berdasarkan hasil analisis pada tabel di atas menunjukan nilai sig $0,026<\alpha=0,05$. Hal ini berarti $\mathrm{H}_{0}$ ditolak. Dengan demikian jenis kelamin laki-laki dan perempuan memiliki tingkat motivasi yang berbeda, sehingga dapat disimpulkan bahwa " Terdapat perbedaan yang signifikan antara tingkat motivasi belajar mahasiswa yang berjenis kelamin laki-laki dengan tingkat motivasi mahasiswa yang berjenis kelamin perempuan.

Sementara pengujian terhadap kemampuan kritis matematis mahasiswa menggunakan hipotesis sebagai berikut:

$\mathrm{H}_{0}=$ tidak terdapat perbedaan yang signifikan antara kemampuan kritis matematis mahasiswa laki-laki dan perempuan

$\mathrm{H}_{1}=$ terdapat perbedaan yang signifikan antara kemampuan kritis matematis mahasiswa laki-laki dan perempuan

Hasil pengolahan data disajikan pada tabel berikut:
Dari seluruh rangkaian analisis data, ditemukan bahwa terdapat hubungan antara motivasi belajar dengan kemampuan berpikir kritis matematis mahasiswa yang dipengaruhi oleh perbedaan jenis kelamin. Pola hubungan yang terbentuk adalah hubungan searah, yaitu motivasi belajar yang tinggi akan menyebabkan tinggi pula skor kemampuan berpikir kritis matematisnya. Sebaliknya, jika motivasi belajar mahasiswa rendah maka mengakibatkan rendahnya skor kemampuan berpikir kritis matematis yang dicapai.

Sedangkan perbedaan jenis kelamin tidak berpengaruh signifikan terhadap kemampuan kritis matematis yang diperoleh mahasiswa. Hasil analisis data menunjukkan bahwa mahasiswa lakilaki dan perempuan memiliki kemampuan berpikir kritis matematis yang beragam.

Tabel 4. Hasil Analisis Kemampuan Berpikir Kritis ditinjau dari Jenis Kelamin Independent Samples Test

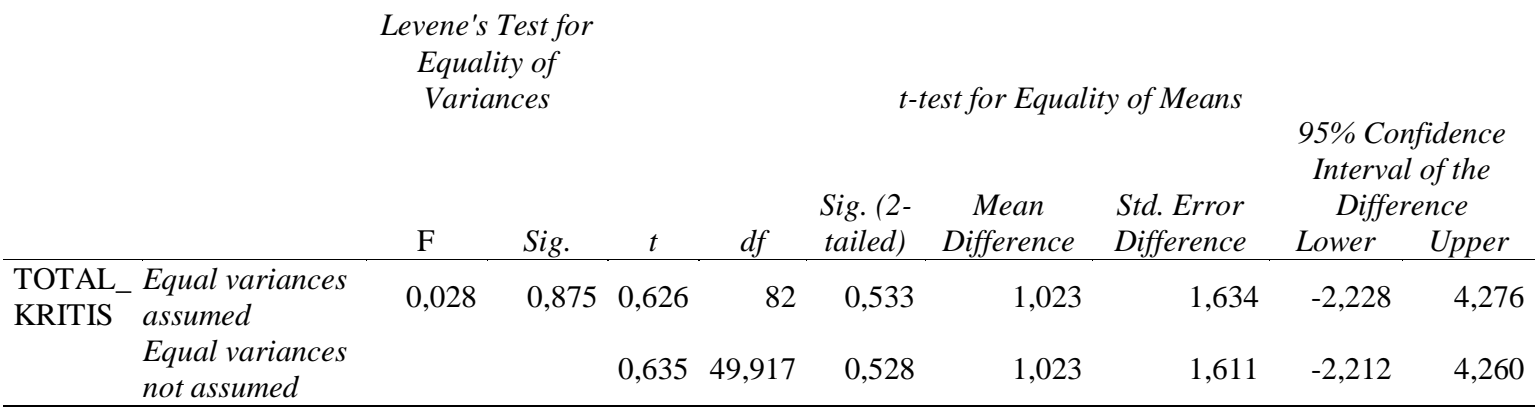


Sehingga muncul dugaan bahwa ada faktor lain yang berpengaruh terhadap pencapaian kemampuan berpikir kritis. Hal ini diperkuat dari hasil wawancara, diperoleh hasil bahwa kemampuan mahasiswa beragam tidak dapat dibedakan atas perbedaan jenis kelamin. Adapun faktor-faktor yang dimungkinkan berpengaruh dalam pencapaian kemampuan berpikir kritis matematis selain motivasi belajar masing-masing mahasiswa yaitu perbedaan gaya belajar tiap individu, latar belakang pilihan jurusan ketika sekolah menengah, kesibukan, karakteristik mata kuliah dan faktor-faktor eksternal lain. Untuk mendeteksi lebih lanjut terkait faktor-faktor tersebut perlu dilakukan penelitian lanjutan.

Faktor-faktor yang mendukung tingginya motivasi belajar mahasiswa salah satunya yaitu minat mahasiswa terhadap mata kuliah. Mahasiswa yang menyukai mata kuliah Struktur Aljabar II cenderung lebih semangat belajar dibanding mahasiswa yang kurang menyukainya. Lebih luas lagi, mahasiswa yang memang menyukai analisis dan penalaran logis matematis memiliki keinginan dan motivasi belajar lebih tinggi dibandingkan mahasiswa yang hanya menyukai perhitunganperhitungan dan hafalan. Karakteristik mata kuliah Struktur Aljabar II salah satunya adalah mata kuliah yang menekankan pada kemampuan mahasiswa menganalisa definisi, aksioma, teorema dan pembuktian aljabar. Hanya sebagian kecil dari materi mata kuliah Struktur Aljabar II yang menuntut perhitungan-perhitungan bilangan. Sedangkan mahasiswa yang kurang menyukai karakteristik tersebut menjadi penghambat untuk memiliki motivasi belajar.

Faktor internal juga memiliki pengaruh terhadap muncul atau tidaknya motivasi belajar mahasiswa. Sikap tidak mudah menyerah dan suka tantangan yang muncul dalam diri mahasiswa mempengaruhi motivasi belajarnya. Hal ini muncul dalam pengamatan selama pembelajaran. Kegagalan dan kesulitan yang dialami beberapa mahasiswa selama mengikuti perkuliahan menyebabkan dirinya malas dan enggan untuk berusaha mencari cara bagaimana dapat memahami dan menguasai materi perkuliahan. Mereka cenderung menarik diri dan pasif, walaupun dosen berusaha untuk memotivasi bahkan memberi bantuan serta mengulang kembali penjelasan terkait suatu materi.

Latar belakang pilihan jurusan ketika sekolah menengah juga menjadi pembeda motivasi belajar mahasiswa. Mahasiswa dari jurusan IPA lebih mudah dan cenderung lebih cepat untuk menguasai dan memahami materi perkuliahan dibanding mahasiswa dari jurusan yang lain. Hal ini dimungkinkan karena di jurusan IPA, siswa terbiasa dengan pelajaran berbasis sciences. Dibeberapa mata pelajaran, siswa dilatih untuk melakukan pembuktian menggunakan prosedur matematis. Perbedaan pilihan jurusan ini juga berpengaruh pada seberapa besar muncul motivasi untuk belajar.

Kemudian latar belakang keluarga, usia dan metode mengajar yang diterapkan dosen juga memberi kontribusi terhadap perbedaan motivasi belajar mahasiswa. Untuk melihat lebih jauh perlu dilakukan penelitian tindak lanjut untuk menggali kembali faktor-faktor lain yang menyebabkan tinggi rendahnya motivasi belajar mahasiswa serta kemampuan berpikir kritis mahasiswa.

\section{KESIMPULAN}

Dari hasil analisis data dan pembahasan ditemukan pengaruh motivasi belajar mahasiswa ditinjau dari perbedaan jenis kelamin terhadap kemampuan berpikir kritis matematis mahasiswa di STKIP Siliwangi Bandung pada Mata Kuliah Struktur Aljabar II. Kemudian terdapat pengaruh yang searah antara motivasi belajar mahasiswa ditinjau dari perbedaan jenis kelamin terhadap kemampuan berpikir kritis matematis mahasiswa di STKIP Siliwangi Bandung pada Mata Kuliah Struktur Aljabar II. Hal ini menunjukkan bahwa tingginya motivasi belajar mahasiswa akan menyebabkan tingginya kemampuan berpikir kritis matematisnya, demikian sebaliknya.

Sedangkan faktor-faktor yang mempengaruhi tinggi rendahnya jenis kelamin salah satunya yaitu: minat mahasiswa terhadap materi perkuliahan, latar belakang pilihan jurusan ketika sekolah menengah, latar belakang keluarga, usia dan metode yang diterapkan dosen saat mengajar.

Dari hasil penelitian ini diperlukan adanya penelitian tindak lanjut untuk menganalisis secara statistik faktor-faktor yang berpengaruh pada motivasi belajar mahasiswa terhadap kemampuan berpikir kritis matematis mahasiswa seperti yang telah dijelaskan.

\section{E. DAFTAR PUSTAKA}

Agustian, A. G. \& Mukri, R. (2007). ESQ For Teens \#1. Jakarta: Penerbit Arga 
Depdiknas. (2002). UU No. 20 Tahun 2003 Tentang Sistem Pendidikan Nasional. Jakarta: Depdiknas

Ennis, R. H. (1996). A Critical Thinking. New York: Freeman

Hoang, T. N. (2008). The Effect of Grade Level, Gender, and Ethnicity on Attitute and Learning Environment in Accounting in High School: International Electronic Journal of Accountuing Education. Vol. 3.

Johnson. (2007). Berpikir Kritis dan Kreatif. Bandung: MLL

Makmun, A. S. (2004). Psikologi Kependidikan. Bandung: PT Remaja Rosdakarya

Nasution, H. (1986). Dedaktik Azas-Azas Mengajar. Bandung: Jemmars

Sardiman, A. M. (2005). Interaksi \& Motivasi Belajar Mengajar. Jakarta: PT Raja Grafindo Persada

Susanto, H. (2013). Kemampuan Berpikir Kritis. [Online]. Tersedia di: https://bagawanabiyasa. wordpress.com /2013/05/02/kemampuan-berpikir-kritis/ Diakses 01 Nopember 2015. 